\title{
Smart Home System Berbasis IoT dan SMS
}

\section{Smart Home System Based on IoT and SMS}

\author{
Heri Andrianto ${ }^{1 *}$, Gandha Intan Saputra ${ }^{2}$ \\ ${ }^{1,2}$ Teknik Elektro, Universitas Kristen Maranatha \\ Jl. Prof. drg. Surya Sumantri, M.P.H. No. 65, Bandung \\ heri.andrianto@eng.maranatha.edu ${ }^{* *}$, gandha1001@gmail.com²
}

\begin{abstract}
Abstrak - Pada umumnya, pemilik rumah merasa cemas ketika meninggalkan rumah dalam jangka waktu yang lama. Kemajuan teknologi pada saat ini memungkinkan pengembangan perangkat IoT untuk melakukan pengawasan dan pengendalian berbagai peralatan elektronik kapan saja dan mana saja. Pada makalah ini, kami telah merancang dan merealisasikan smart home system berbasis IoT dan SMS untuk mengendalikan dan mengawasi peralatan elektronik rumah serta mengirimkan pemberitahuan kejadian penting kepada pemilik rumah melalui SMS. Pengawasan dan pengendalian peralatan elektronik rumah dilakukan melalui web, sedangkan pemberitahuan adanya pencuri dan kebocoran gas dikirimkan kepada pemilik rumah melalui SMS. Perangkat keras yang digunakan pada smart home system terdiri dari arduino mega2560, modul IoT (Esp8266), modul GSM (SIM800L), sensor gerakan (PIR), sensor suhu dan kelembaban (DHT11), sensor cahaya (LDR), sensor gas (MQ2), dan modul RTC (DS1307). Hasil pengujian smart home system secara keseluruhan menunjukan bahwa sistem telah berfungsi dengan baik dan memiliki tingkat keberhasilan sebesar $100 \%$.
\end{abstract}

Kata Kunci: Pemberitahuan, IoT, smart home system, SMS.

\begin{abstract}
In generally, home owners feel worried when leaving the house for a long time. Technological advances currently allow the development of IoT devices to conduct surveillance and control of various electronic equipment anytime and anywhere. In this paper, we have designed and realized an IoT and SMSbased smart home system to control and supervise home electronic equipment and send notifications of important events to homeowners via SMS. Supervision and control of home electronic equipment is carried out via the web, while notifications of burglars and gas leaks are sent to homeowners via SMS. The hardware used in the smart home system consists of Arduino Mega2560, IoT module (Esp8266), GSM module (SIM800L), motion sensor (PIR), temperature and humidity sensor (DHT11), light sensor (LDR), gas sensor (MQ2), and RTC modules (DS1307). The overall smart home system test results show that the system is functioning properly and has a success rate of $100 \%$.
\end{abstract}

Keywords: Notification, IoT, smart home system, SMS.

\section{Pendahuluan}

Tempat tinggal yang aman dan nyaman untuk dihuni merupakan keinginan setiap orang. Namun, banyak orang merasa cemas ketika meninggalkan rumahnya dalam keadaan kosong untuk jangka waktu yang lama, hal ini mendorong manusia untuk membuat smart home system. Smart home merupakan cabang dari ubiquitous computing yang memasukkan kecerdasan ke dalam rumah untuk kenyamanan, kesehatan, keselamatan, keamanan, dan konservasi energi. Sistem pemantauan jarak jauh adalah komponen umum dari smart home, yang menggunakan

TELKA, Vol.6, No.1, Mei 2020, pp. 40 48

ISSN (e): 2540-9123

ISSN (p): 2502-1982 
teknologi telekomunikasi dan web untuk memberikan informasi mengenai kondisi rumah serta dapat mengendalikan peralatan listrik yang ada di rumah secara jarak jauh [1].

Saat ini, pengendalian dan pengawasan berbagai perangkat elektronik di rumah secara jarak jauh dimungkinkan dengan adanya perkembangan teknologi Internet of Things (IoT). Pengertian IoT menurut Ray P. P yaitu, IoT adalah jaringan luas dari objek-objek yang saling berhubungan yang dapat dialamati secara unik, berdasarkan pada protokol komunikasi standar [2]. Selain itu Ray P. P juga menyatakan bahwa IoT adalah penggabungan beberapa "things" dengan memanfaatkan internet sebagai tulang punggung sistem komunikasi untuk membangun interaksi yang cerdas antara orang dan benda-benda di sekitarnya [3]. Menurut Georgakopoulos dan Jayaraman, IoT adalah evolusi web terbaru yang menggabungkan miliaran perangkat (seperti kamera, sensor, RFID, ponsel pintar, dan perangkat pintar lainnya), yang dimiliki oleh berbagai organisasi dan orang yang menyebarkan dan menggunakannya untuk tujuan mereka sendiri [4]. Teknologi IoT dapat digunakan pada smart home system [5], dengan menggunakan teknologi IoT, pemilik rumah tidak perlu merasa cemas saat meninggalkan rumah untuk jangka waktu yang cukup panjang. Pengendalian dan monitoring jarak jauh dapat dilakukan baik melalui personal computer maupun melalui smartphone asalkan terhubung ke internet.

Penelitian-penelitian mengenai smart home khususnya untuk pengendalian dan monitoring peralatan listrik di rumah telah dilakukan. Prihatmoko telah merancang sistem otomatisasi rumah melalui internet yang dapat secara otomatis memonitor dan mengontrol keadaan rumah dari jarak jauh dengan tujuan untuk menghemat energi [6]. Mao dkk merancang smart home system menggunakan teknik komunikasi sensor nirkabel ZigBee, yang dikombinasikan dengan teknologi jaringan 3G/4G, sistem pemantauan jarak jauh rumah cerdas dikembangkan berdasarkan embedded web gateway, server cloud, dan aplikasi ponsel pintar [7]. Dahoumane dkk telah merancang smart home system berbasis webservice dan Global System for Mobile Communications (GSM) [8]. Wardoyo dkk telah merancang smart home system yang memiliki fitur akses terhadap pintu dengan metode autentifikasi password dan biometric fingerprint serta fasilitas tambahan emergency backup supply dan emergency entry [9]. Li dkk merancang dan mengimplementasikan smart home system berbasis wireless sensor network (WSN) dan powerline communication [10].

Pada penelitian ini, kami telah merancang dan merealisasikan smart home system berbasis IoT dan layanan pemberitahuan kejadian penting melalui SMS. Tujuan utama dari penelitian ini yaitu merancang dan membuat smart home system untuk kenyamanan, penghematan energi dan keamanan rumah dari bahaya pencurian dan kebakaran akibat kebocoran gas. Smart home system ini dirancang menggunakan sensor gerakan (PIR) untuk mendeteksi adanya pencurian, sensor suhu dan kelembaban (DHT11) untuk membaca suhu udara, sensor cahaya (LDR) untuk mendetekasi intensitas cahaya dan sensor pendeteksi gas (MQ2) untuk mendeteksi kebocoran gas LPG. Esp8266 digunakan untuk menghubungkan arduino ke internet. Modul GSM (SIM800L) digunakan untuk mengirimkan pemberitahuan melalui SMS kepada pemilik rumah apabila sensor mendeteksi adanya pergerakan dan kebocoran gas. RTC DS1307 digunakan sebagai referensi waktu secara real time untuk keperluan penjadwalan. Sedangkan perangkat yang dikendalikan terdiri atas lampu, kipas, dan buzzer. Webservice dirancang sebagai layanan untuk komunikasi data antara server dengan perangkat IoT dalam rangka memonitor hasil pembacaan sensor dan mengendalikan aktuator selama terhubung dengan koneksi internet.

\section{Metode Penelitian}

Metode penelitian terdiri dari empat tahap. Tahap pertama, merancang arsitektur smart home system berbasis IoT dan GSM (Gambar 1). Tahap kedua, merancang dan merealisasikan perangkat IoT berbasis Arduino mega2560 dan modul IoT Esp8266 untuk keperluan smart home system. Tahap ketiga, menguji perangkat IoT. Tahap keempat, mengevaluasi kinerja perangkat IoT.

Tahap pertama yaitu merancang arsitektur smart home system berbasis IoT dan layanan SMS. Arsitektur smart home system berbasis IoT terdiri dari perangkat IoT, modul GSM 
(SIM800L), modul WiFi (Esp8266), akses point nirkabel (wireless router), server aplikasi dan perangkat pemantauan jarak jauh (personal computer dan smartphone).

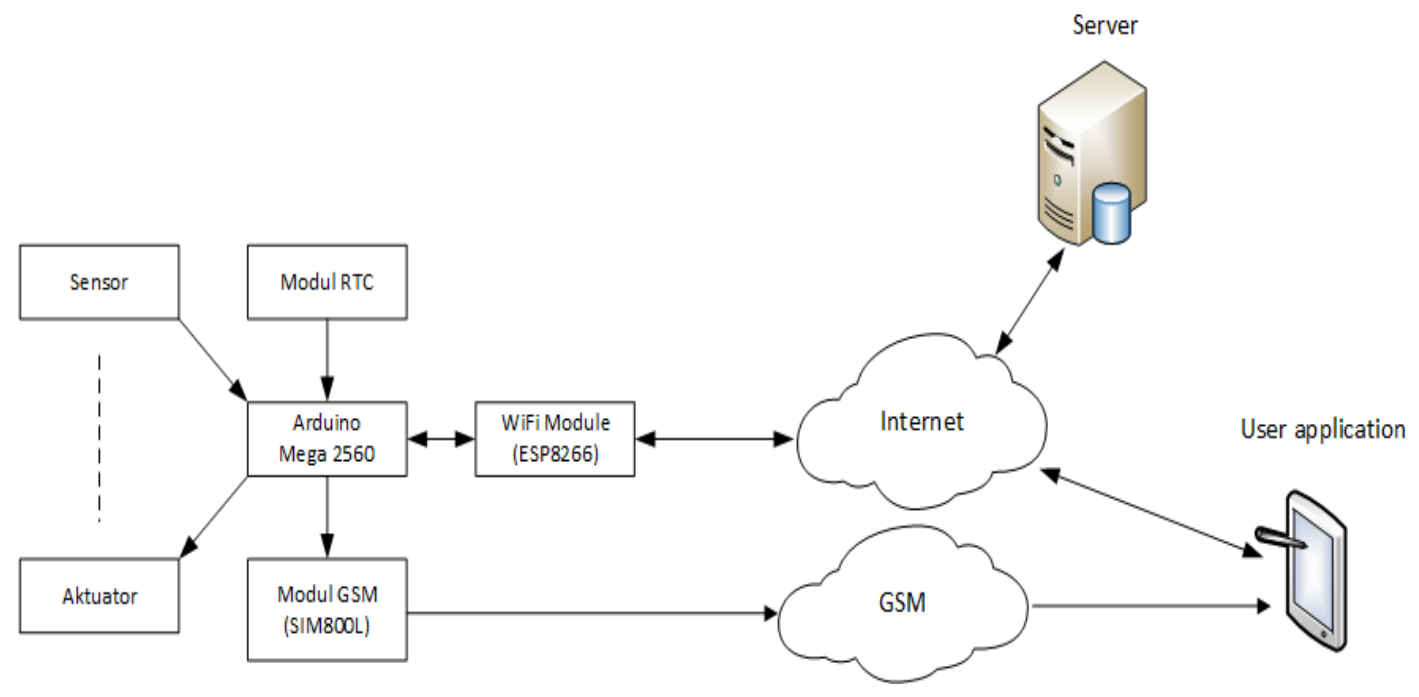

Gambar 1. Arsitektur smart home system berbasis IoT dan SMS.

Arduino dihubungkan ke internet melalui koneksi WiFi menggunakan modul Esp8266. Modul GSM SIM800L digunakan untuk mengirimkan SMS peringatan kepada pemilik rumah pada saat sensor membaca adanya pergerakan/pencuri dan kebocoran gas. Web dirancang untuk dapat memperbarui data secara berkala sehingga data/status yang ditampilkan pada web adalah data terbaru dari pembacaan sensor. Selain itu, web dirancang untuk memudahkan pengendalian lampu, kipas, dan buzzer secara manual serta memonitor status peralatan listrik yang ada. Smart home system yang dibangun ditujukan untuk keperluan keamanan dari bahaya pencuri, penghematan energi, dan peringatan dini akan adanya bahaya kebakaran.

Prinsip kerja sistem untuk keperluan keamanan dari bahaya pencuri yaitu sensor PIR mendeteksi adanya gerakan pada saat smart home system diaktifkan. Apabila terdeteksi adanya gerakan pada saat sistem keamanan diaktifkan maka sistem keamanan akan memicu buzzer aktif, mengirimkan SMS peringatan adanya pencurian kepada smartphone pemilik rumah, dan menampilkan status adanya pergerakan/pencuri pada web.

Prinsip kerja sistem untuk keperluan penghematan energi yaitu sensor DHT11 mendeteksi suhu ruangan, apabila suhu di dalam ruangan di atas setpoint dan ada orang, maka kipas angin akan aktif secara otomatis. Sensor LDR mendeteksi intensitas cahaya, apabila sensor mendapatkan cahaya yang cukup maka lampu akan padam sedangkan pada saat sensor tidak mendapatkan cukup cahaya dan ada orang maka lampu akan nyala. RTC DS1307 digunakan sebagai sumber data waktu secara real time untuk penjadwalan yaitu pada pukul 18.00 WIB lampu teras akan nyala secara otomatis dan padam pada pukul 06.00 WIB. Prinsip kerja untuk keperluan peringatan dini akan adanya bahaya kebakaran yaitu sensor MQ2 mendeteksi adanya gas dengan intensitas tinggi dan memusat. Sensor ini ditujukan untuk mendeteksi terjadinya kebocoran gas pada saat sistem keamanan diaktifkan. Apabila sensor mendeteksi adanya gas dengan intensitas tinggi dan memusat pada saat sistem keamanan diaktifkan, maka sistem keamanan akan memicu buzzer aktif, mengirimkan SMS peringatan kebocoran gas kepada pengguna, dan menampilkan status adanya kebocoran gas pada web.

Tahap kedua yaitu merancang dan merealisasikan perangkat IoT berbasis Arduino mega2560 dan modul IoT (Esp8266) untuk keperluan smart home system. Tabel 1 menunjukan perancangan perangkat IoT yaitu wiring pin input dan output Arduino Mega2560 dengan komponen lainnya. Gambar 2 menunjukan perangkat IoT untuk smart home system yang sudah direalisasikan. 
Tabel 1. Wiring pin input dan output Arduino Mega2560 dengan komponen lainnya.

\begin{tabular}{cc}
\hline Arduino Mega 2560 & Input/output \\
\hline VCC 5V & VCC (DHT11, MQ2, PIR, LDR, RTC DS1307, SIM800L \\
(DC converter 4V), Relay 2 Channel) & VCC Esp8266 \\
VCC 3.3V & GND (Esp8266, DHT11, MQ2, PIR, RTC DS1307, \\
GND & SIM800L, Relay 2 Channel) \\
TX1 & RX1 Esp8266 \\
RX1 & TX1 Esp8266 \\
TX2 & RX SIM800L \\
RX2 & TX SIM800L \\
A0 & Output MQ2 \\
A1 & LDR \\
SDA & SDA RTC DS1307 \\
SCL & SCL RTC DS1307 \\
PIN 22 & DATA DHT11 \\
PIN 23 & Output PIR \\
PIN 30 & Kipas (Relay IN2) \\
PIN 32 & Lampu (Relay IN1) \\
\hline
\end{tabular}

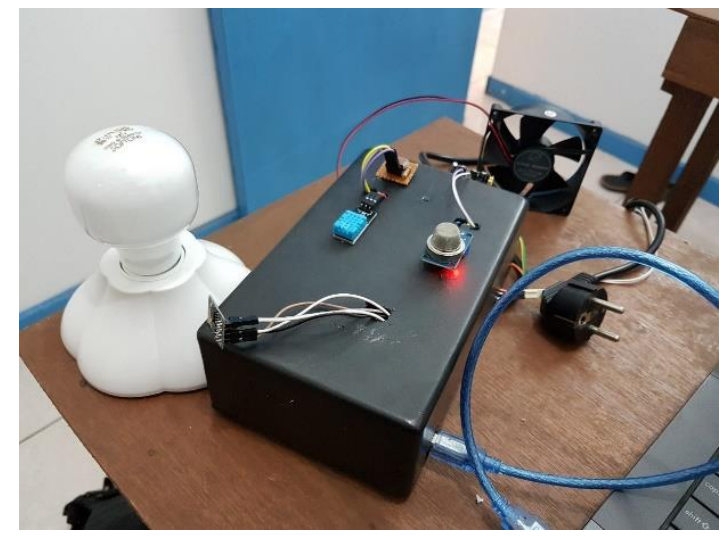

Gambar 2. Perangkat IoT untuk smart home system.

Diagram alir program pada Arduino mega 2560 dengan modul Esp8266, diawali dengan inisialisasi komponen-komponen yang digunakan serta menghubungkan modul Esp8266 dengan wifi router yang terkoneksi internet, proses selanjutnya yaitu membaca nilai yang dibaca dari RTC, sensor PIR, sensor MQ2, sensor DHT11, dan sensor LDR. Jika RTC DS1307 menunjukan waktu antara pukul 06.00 WIB sampai dengan pukul $18.00 \mathrm{WIB}$, maka relay akan off sehingga lampu teras akan padam, di luar itu maka lampu teras akan on. Jika nilai yang dibaca dari sensor PIR menujukan adanya gerakan, maka buzzer akan aktif dan SMS peringatan adanya pencurian dikirim ke smartphone pemilik rumah. Apabila nilai yang dibaca dari sensor LDR lebih kecil dari nilai set point cahaya dan nilai yang dibaca dari sensor PIR menunjukan adanya gerakan, maka relay akan aktif sehingga lampu menyala. Jika nilai yang dibaca dari sensor MQ2 lebih besar dari nilai set point gas maka buzzer akan aktif dan SMS peringatan kebocoran gas dikirim ke smartphone pengguna. Jika nilai yang dibaca dari sensor DHT11 lebih besar dari nilai set point suhu dan sensor PIR mendeteksi ada orang maka relay akan aktif sehingga kipas menyala. Hasil dari pembacaan nilai sensor akan dikirim ke database dengan metode post. Proses pengiriman data diberi nama postRequest(). Setelah data dikirim ke database, arduino akan mendapatkan feedback dari webservice. Proses feedback ini diberi nama httppost(). Apabila arduino tidak mendapatkan catu daya maka proses akan selesai. Tetapi apabila masih ada catu daya yang diberikan pada arduino maka sistem akan kembali membaca sensor dan seterusnya. 


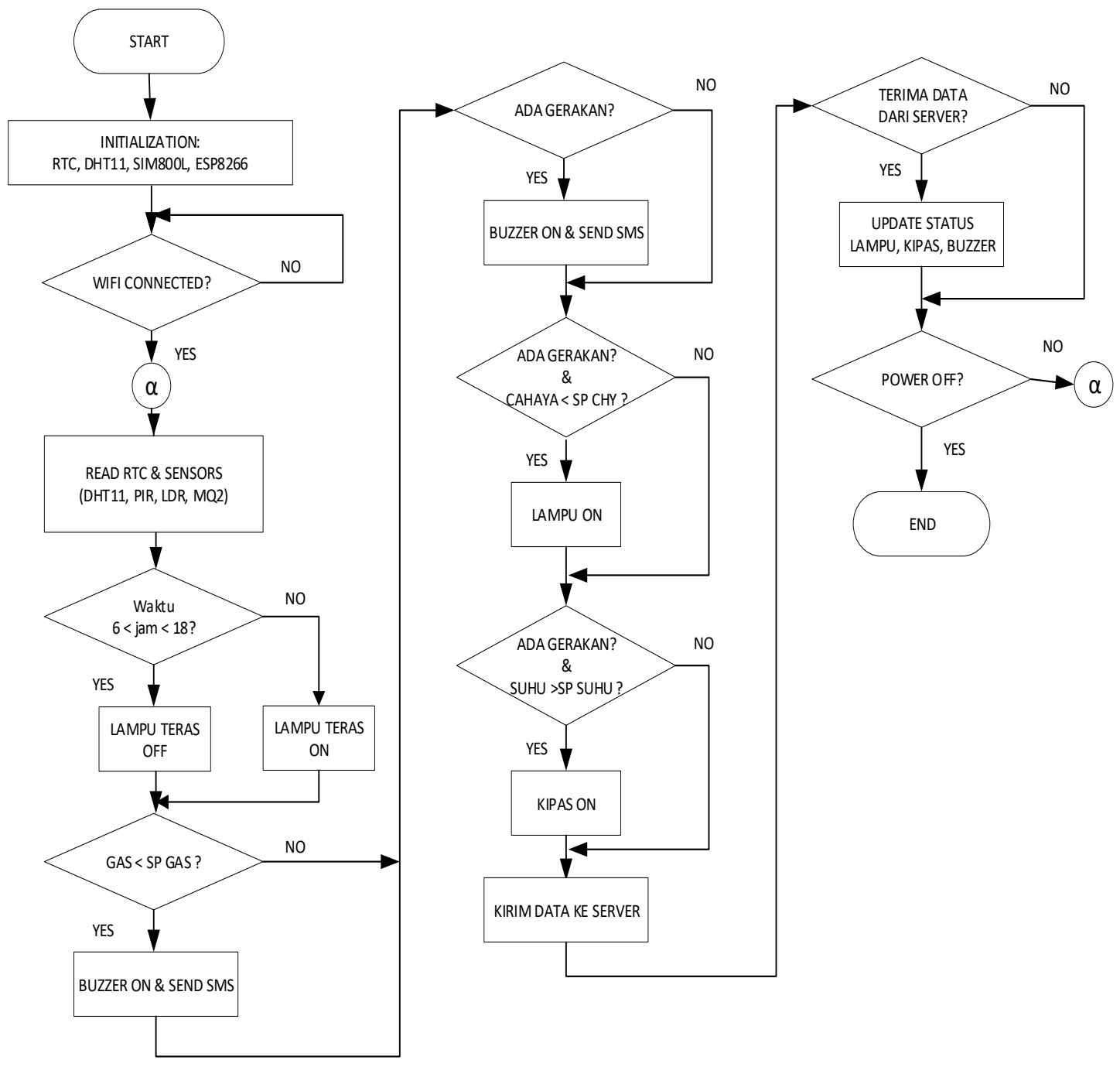

Gambar 3. Diagram alir program pada Arduino Mega 2560.

Diagram alir program pada Arduino Mega 2560 dapat dilihat pada Gambar 3. .Diagram alir program pada program web mode otomatis, dimulai dengan menunggu data yang dikirim dari Arduino mega 2560. Setelah data diterima, data tersebut akan diinput ke database mysql. Setelah data terbaru diinput ke database, data tersebut akan diupdate ke tampilan web, kemudian web akan membaca kondisi terbaru dari output. Hasil pembacaan kondisi terbaru dari output ini akan di kirim kembali ke arduino sebagai feedback untuk memastikan kondisi terakhir dari output. Apabila catu daya tidak ada maka proses selesai. Apabila catu daya masih ada maka proses akan kembali pada menunggu data yang dikirim dari arduino.

Diagram alir program web baik manual maupun otomatis dapat dilihat pada Gambar 4. Diagram alir program web mode manual, diawali ketika button lampu ditekan, lalu membaca status lampu pada database, kemudian meng-update button lampu pada database mysql serta mengirimkan data ke arduino. Ketika button kipas ditekan, lalu melakukan pembacaan status kipas pada database, kemudian meng-update button kipas pada database mySql serta mengirimkan data ke arduino. Ketika button buzzer ditekan, lalu melakukan pembacaan status buzzer pada database, kemudian meng-update button buzzer pada database mysql serta mengirimkan data ke arduino. Apabila catu daya tidak ada, maka proses mode manual selesai. Jika catu daya masih ada maka kembali ke proses awal. 


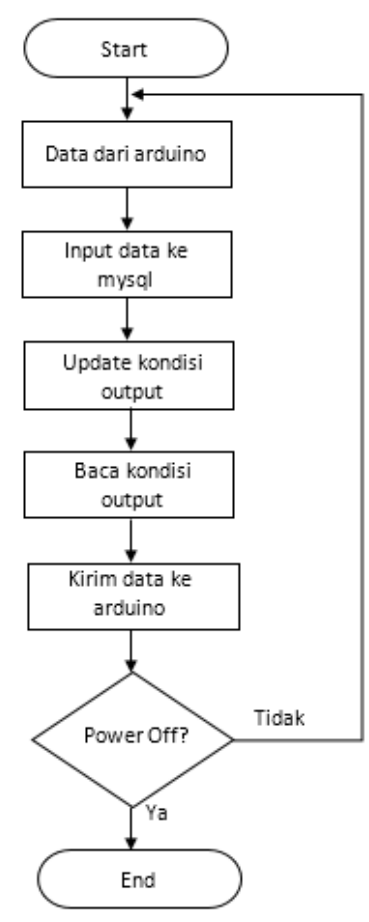

(a)

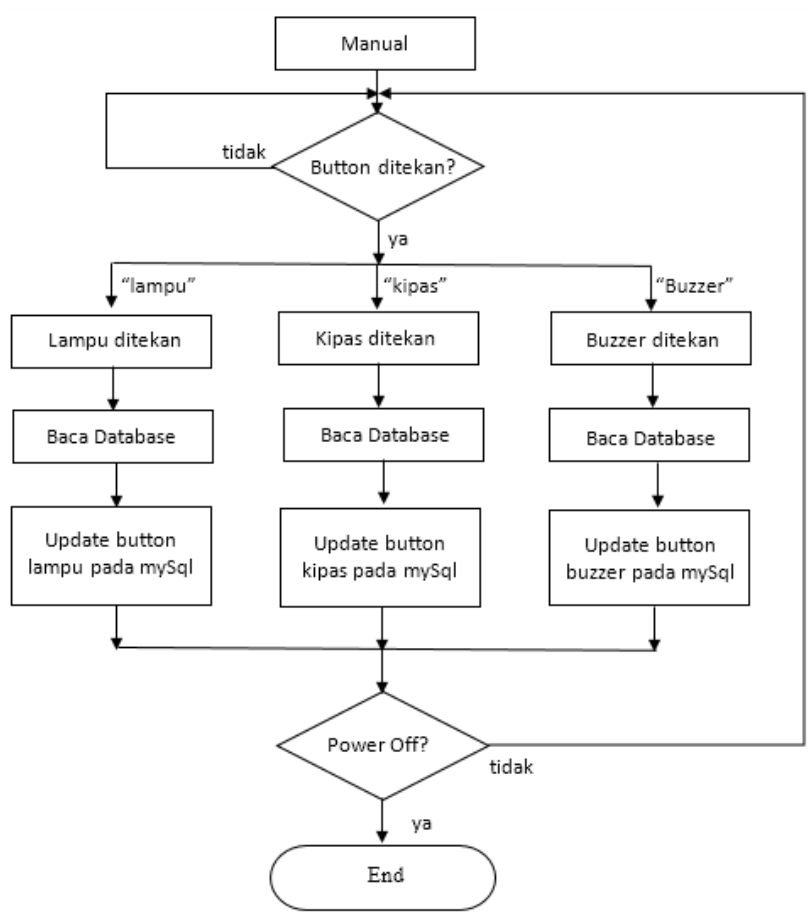

(b)

Gambar 4. Flowchart program : (a) web mode otomatis, (b) web mode manual.

Web untuk mengendalikan dan mengawasi smart home system dapat dilihat pada Gambar 5. Peralatan listrik yang dapat dikendalikan dari web berupa lampu, kipas, dan buzzer. Hal yang dapat diawasi yaitu suhu ruangan, kondisi ruangan (ada atau tidak ada orang), kondisi gas (aman/bahaya), cahaya rungan (terang/gelap) dan lampu teras (nyala/padam).

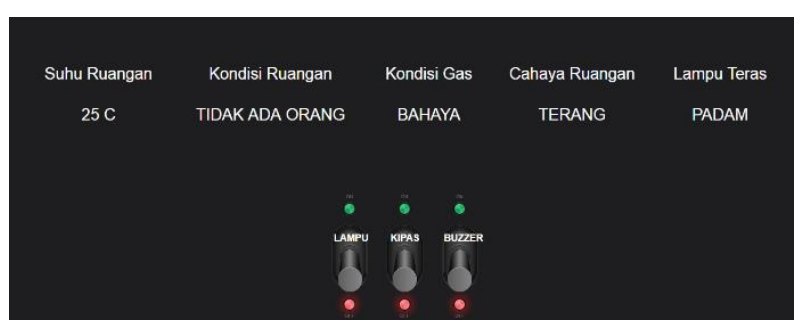

Gambar 5. Web smart home system.

\section{Hasil dan Pembahasan}

Dahoumane dkk [8] merancang arsitektur smart home system menggunakan jaringan internet dan GSM berbasis modul XBee ZigBee, Raspberry pi dan modem GSM. Namun, Dahoumane dkk hanya melaporkan arsitektur smart home system, sedangkan hasil pengujian sistem yang dibangun tidak dilaporkan. Pada penelitian ini, kami mengembangkan smart home system berbasis IoT dan layanan SMS. Informasi yang penting seperti bahaya pencurian dan kebocoran gas harus diinformasikan langsung kepada pemilik rumah dengan cepat, sehingga digunakan pengiriman pesan melalui SMS, sedangkan untuk pengendalian dan monitoring peralatan listrik seperti lampu, kipas dan buzzer dapat dilakukan melalui aplikasi web. 
Pada penelitian ini, pengujian deteksi adanya gerakan dilakukan dengan cara melihat kondisi tampilan web pada saat sensor PIR membaca adanya gerakan (ada orang). Hal yang diuji adalah status dari sensor PIR, tampilan web, delay tampilan, SMS peringatan, delay SMS peringatan, dan kondisi buzzer. Pada saat sensor PIR mendeteksi adanya gerakan/orang maka tampilan pada web akan menampilkan kondisi ada orang, kemudian modul SIM800L akan mengirimkan SMS peringatan kepada smartphone pengguna dan buzzer akan berbunyi. Tabel 2 menunjukan hasil pengujian deteksi adanya gerakan/orang, dengan tingkat keberhasilan sebesar 100\%, rata-rata waktu pengiriman pesan SMS sebesar $2 \mathrm{~s}$, dan rata-rata delay tampilan web sebesar 12,5 s.

Tabel 2. Hasil pengujian deteksi adanya gerakan/orang.

\begin{tabular}{cccccc}
\hline Sensor PIR & Tampilan Web & Delay Tampilan & $\begin{array}{c}\text { SIM800L } \\
\text { (SMS) }\end{array}$ & Delay SMS & Buzzer \\
\hline 1 & Ada Orang & $13 \mathrm{~s}$ & Kirim Pesan & $2 \mathrm{~s}$ & On \\
1 & Ada Orang & $10 \mathrm{~s}$ & Kirim Pesan & $2 \mathrm{~s}$ & On \\
0 & Tidak Ada Orang & $15 \mathrm{~s}$ & - & - & Off \\
0 & Tidak Ada Orang & $12 \mathrm{~s}$ & - & - & Off \\
\hline
\end{tabular}

Pengujian deteksi adanya kebocoran gas dilakukan dengan cara melihat kondisi tampilan web pada saat sensor MQ2 membaca adanya gas yang melewati nilai set point gas. Hal yang diuji adalah kondisi dari sensor MQ2, tampilan web, delay tampilan, sms peringatan, delay sms peringatan, dan kondisi buzzer. Pada saat sensor MQ2 membaca adanya gas terpusat yang melewati nilai set point gas maka tampilan pada web akan menampilkan kondisi bahaya, kemudian SIM800L akan mengirimkan SMS peringatan kepada pengguna dan buzzer akan berbunyi. Tabel 3 menunjukan hasil pengujian deteksi adanya kebocoran gas, dengan tingkat keberhasilan sebesar $100 \%$, rata-rata waktu pengiriman pesan SMS sebesar 15,3 s dan rata-rata delay tampilan web sebesar 34,2 s.

Tabel 3. Hasil pengujian deteksi adanya kebocoran gas.

\begin{tabular}{cccccc}
\hline Sensor MQ2 & Tampilan Web & Delay Tampilan & SIM800L (SMS) & Delay SMS & Buzzer \\
\hline Diberikan Gas & Bahaya & $36 \mathrm{~s}$ & Kirim Pesan & $14 \mathrm{~s}$ & On \\
Diberikan Gas & Bahaya & $38 \mathrm{~s}$ & Kirim Pesan & $14 \mathrm{~s}$ & On \\
Diberikan Gas & Bahaya & $35 \mathrm{~s}$ & Kirim Pesan & $18 \mathrm{~s}$ & On \\
Normal & Aman & $31 \mathrm{~s}$ & - & - & Off \\
Normal & Aman & $31 \mathrm{~s}$ & - & - & Off \\
\hline
\end{tabular}

Pengujian kipas otomatis dilakukan dengan cara melihat kondisi tampilan web pada saat suhu yang dibaca sensor DHT11 berada di atas nilai set point suhu dan sensor PIR membaca ada orang. Hal yang diuji adalah hasil pembacaan suhu, hasil pembacaan sensor PIR, tampilan web, delay tampilan, kondisi kipas dan delay kipas. Pada saat suhu yang dibaca sensor DHT11 berada di atas nilai set point suhu dan sensor PIR membaca ada orang maka kipas akan hidup secara otomatis. Hasil pembacaan sensor akan ditampilkan pada web. Tabel 4 menunjukan hasil pengujian pengendalian dan monitoring kipas dengan tingkat keberhasilan sebesar 100\% dan ratarata delay tampilan web sebesar $13,5 \mathrm{~s}$.

Tabel 4. Hasil pengujian pengendalian dan monitoring kipas.

\begin{tabular}{ccccc}
\hline Suhu $\left({ }^{\circ} \mathrm{C}\right)$ & ada_orang & Delay Tampilan & Kipas & Delay Kipas \\
\hline 26 & 0 & $8 \mathrm{~s}$ & Off & - \\
30 & 1 & $8 \mathrm{~s}$ & Off & - \\
33 & 1 & $14 \mathrm{~s}$ & On & On \\
59 & 1 & $23 \mathrm{~s}$ & On & - \\
43 & 0 & $14 \mathrm{~s}$ & Off & $7 \mathrm{~s}$ \\
32 & 1 & $14 \mathrm{~s}$ & On & \\
\hline
\end{tabular}

Keterangan: Set point $=30^{\circ} \mathrm{C}$

Kipas On $=$ Suhu $>$ Set point $\& \&$ ada_orang $=1$

Pengujian lampu otomatis dilakukan dengan cara melihat kondisi tampilan web pada saat sensor LDR tidak mendapatkan cahaya yang cukup (di bawah batas nilai set point cahaya) dan 
sensor PIR membaca ada orang. Hal yang diuji adalah hasil pembacaan sensor LDR, hasil pembacaan sensor PIR, tampilan web delay tampilan, kondisi lampu dan delay lampu. Tabel 5 menunjukan hasil pengujian pengendalian dan monitoring lampu dengan tingkat keberhasilan sebesar $100 \%$, rata-rata delay tampilan web sebesar $24,3 \mathrm{~s}$ dan rata-rata delay respon lampu terhadap pembacaan sensor LDR sebesar $10 \mathrm{~s}$.

Tabel 5. Hasil pengujian lampu.

\begin{tabular}{cccccc}
\hline Sensor LDR & ada_orang & Tampilan Web & Delay Tampilan & Lampu & Delay Lampu \\
\hline Terang & 1 & Terang & $10 \mathrm{~s}$ & Off & - \\
Terang & 1 & Terang & $25 \mathrm{~s}$ & Off & - \\
Terang & 0 & Terang & $23 \mathrm{~s}$ & Off & - \\
Gelap & 0 & Gelap & $37 \mathrm{~s}$ & Off & - \\
Gelap & 1 & Gelap & $24 \mathrm{~s}$ & On & $8 \mathrm{~s}$ \\
Gelap & 1 & Gelap & $27 \mathrm{~s}$ & On & $12 \mathrm{~s}$ \\
\hline
\end{tabular}

Keterangan: Gelap $=$ nilai_LDR $<200$

Terang $=$ nilai $\_$LDR $>200$

Lampu On $=$ nilai_LDR $<200 \& \&$ ada_orang $=1$

Pengujian monitoring lampu teras dilakukan dengan cara melihat waktu yang didapat dari modul RTC DS1307. Hal yang diuji adalah hasil pembacaan modul RTC DS1307, tampilan web, delay tampilan, kondisi lampu teras dan delay lampu teras. Tabel 6 menunjukan hasil pengujian monitoring lampu teras dengan tingkat keberhasilan sebesar $100 \%$ dan rata-rata delay tampilan web sebesar 5,5 s.

Tabel 6. Hasil pengujian monitoring lampu teras.

\begin{tabular}{ccccc}
\hline Waktu & Tampilan web & Delay Tampilan & $\begin{array}{c}\text { Kondisi Lampu } \\
\text { Teras }\end{array}$ & $\begin{array}{c}\text { Delay Lampu } \\
\text { Teras }\end{array}$ \\
\hline 17:59:50 & Padam & $6 \mathrm{~s}$ & Off & $3 \mathrm{~s}$ \\
18:00:00 & Hidup & $4 \mathrm{~s}$ & On & $3 \mathrm{~s}$ \\
05:59:50 & Hidup & $6 \mathrm{~s}$ & On & $4 \mathrm{~s}$ \\
06:00:00 & Padam & $6 \mathrm{~s}$ & Off & $3 \mathrm{~s}$ \\
\hline
\end{tabular}

Keterangan: Lampu teras on jam 18.00

Lampu teras off jam 06.00

\section{Kesimpulan}

Berdasarkan hasil pengujian, dapat disimpulkan bahwa smart home system yang terdiri dari perangkat IoT, layanan SMS dan aplikasi web telah berhasil rancang dan direalisasikan. Pengendalian dan monitoring peralatan listrik (lampu, kipas, dan buzzer) rumah melalui web berjalan dengan baik dengan tingkat keberhasilan 100\%. Perangkat IoT dapat mengirimkan data ke server serta menerima data dari server, selain itu perangkat IoT juga dapat mengirimkan informasi peringatan dini akan adanya bahaya pencuri dan kebakaran karena kebocoran gas dalam bentuk pesan SMS ke smartphone pemilik rumah. Rata-rata delay waktu SMS sebesar 8,65 s dan rata-rata delay waktu respon tampilan web sebesar $18 \mathrm{~s}$.

\section{Referensi}

[1] M. R. Alam, S. Member, M. Bin, I. Reaz, M. Alauddin, and M. Ali, "A Review of Smart Homes - Past, Present , and Future," IEEE Transactions on Systems, Man, and Cybernetics, Part C (Applications and Reviews), vol. 42, no. 6, pp. 1190-1203, 2012.

[2] P. P. Ray, "A survey on Internet of Things architectures," Journal of King Saud University - Computer and Information Sciences, vol. 30, no. 3, pp. 291-319, 2018.

[3] P. P. Ray, "A survey of IoT cloud platforms," Future Computing and Informatics Journal, vol. 1, no. 1-2, pp. 35-46, 2016.

[4] D. Georgakopoulos and P. P. Jayaraman, "Internet of things : from internet scale sensing 
to smart services," Computing, vol. 98, no. 10, pp. 1041-1058, 2016.

[5] I. A. Zualkernan, M. Rashid, R. Gupta, and M. Alikarar, "A Smart Home Energy Management System Using IoT and Big Data Analytics Approach," vol. 63, no. 4, pp. 426434, 2017.

[6] D. Prihatmoko, "Perancangan Sistem Monitoring Perangkat Elektronik," Jurnal Simetris, vol. 9, no. 1, pp. 279-286, 2018.

[7] X. Mao, K. Li, Z. Zhang, and J. Liang, "Design and Implementation of a New Smart Home Control System Based on Internet of Things," in 2017 International Smart Cities Conference (ISC2), 2017.

[8] T. Dahoumane, M. Haddadi, and Z. Amokrane, "Web Services and GSM based Smart Home Control System," in 2018 International Conference on Applied Smart Systems (ICASS'2018), 2018, no. November, pp. 24-25.

[9] J. Wardoyo, N. Hadullah, and A. B. Utomo, "Smart Home Security System Berbasis Mikrokontroler," Jurnal Simetris, vol. 10, no. 1, pp. 367-374, 2019.

[10] M. Li and H. Lin, "Design and Implementation of Smart Home Control Systems Based on Wireless Sensor Networks and Power Line Communications," IEEE Transactions on Industrial Electronics, vol. 62, no. 7, pp. 4430-4442, 2015. 